\title{
Radical Publishing to "Reach the Million Masses": Alexander L. Trachtenberg and International Publishers, 1906-1966
}

\section{David A. Lincove}

On 21 June 1951 the New York Times published several detailed stories about the FBI's arrest of American communists accused of violating the Smith Act, a 1940 federal statute that made it a crime to advocate, teach, organize, or help to organize the overthrow of the US government by means of force and violence. I Among them was Alexander Leo Trachtenberg, part owner and operator of International Publishers, a New York publishing house specializing in Marxist-Leninist books and pamphlets. After openly operating his publishing firm for 27 years, he now had to defend himself against the charge of publishing, circulating, and promoting books, articles, magazines, and newspapers that taught and advocated the violent overthrow of the US government. ${ }^{2}$ International Publishers contributed to the tremendous increase of propaganda and radical literature in the United States in the decades following World War I when fascist and communist regimes in Europe used the mass media to export ideas that competed with the democratic and capitalist foundation in the United States. Trachtenberg faced years of court battles and three months in prison before his convictions would be overturned; but instead of focusing on his legal struggles, this article examines his background and the operation of International Publishers from 1924 until his retirement in 1962. The case of Alexander Trachtenberg illustrates how a refugee from Russia became a leader in the Communist Party of the United States (CPUS) and established a disciplined, mass publication program to support the party's program for revolutionary socialism. He developed an unwavering commitment to the communist cause that helped him adjust to shifting Soviet ideology and withstand years of government surveillance. International Publishers operated without a break during his lifetime and continues to operate to this day. ${ }^{3}$

Trachtenberg was born in the Black Sea port of Odessa in November 1884. ${ }^{4}$ Odessa was located in the Pale of Settlement, a region in the Western Russian Empire (Ukraine) where most of Russia's Jews were required to live when the state established it in 1791 after the partition of Poland left a large number of Jews in Russian territory. Like other Jews of his generation, he grew up resenting Russia's official policy of restricting the rights of the Jewish population, and this resentment probably provided the spark that influenced his political activities in the future. While a student at Yale in 1912 he explained to an interviewer for the periodical The American Hebrew that

85

(C) Left History

10.1 (Fall/Winter 2004) 
one cannot live in that hell and a hell $\mathrm{i}[\mathrm{t}]$ has been made for our people.... The young men and women of Jewish faith are allowed into the higher spheres of learning in the smallest possible numbers. They must fill only the lowest positions. The Jewish people as a class with the exception of a few fortunates, lives in the deepest misery as do the peasants themselves. We tried to cry out against the inhumanity and the unfairness of it all, but it availed us nothing. ${ }^{5}$

When Trachtenberg spoke these words he clearly identified as a Jew, but he was deeply involved in the socialist movement in America, and it is unlikely that he felt anything for the Jewish religion or the Zionist movement. Indeed his future writings would reflect Lenin's sharp critique of both anti-Semitism and Zionism as expressions of bourgeois nationalism. ${ }^{6}$ The Jewish socialists in Russia who opposed the Zionist idea usually identified with the Bund or General Jewish Labor Union of Lithuania, Poland, and Russia founded in 1897. They favored changing the political and social establishment at home and strived for recognition of Jews as an official minority. The Bund placed itself within the general movement for reform or revolution in Russia. Many other young Jewish socialists did not see any inconsistency between socialism and Jewish or Zionist identification, and usually they associated with socialistZionist groups. Melech Epstein, a Russian-born Jew who immigrated to the United States and later joined the CPUS, supported the socialist-Zionists while he was in Russia because they "sought to fuse our sentiment for a Jewish homeland - a negation of the Galut - with the urge for social justice and economic equality."7 Although there is no evidence of Trachtenberg's thoughts about Zionism before he left Russia, he would have agreed with Epstein's assessment that young Jewish revolutionaries of the period focused on "arousing the people to struggle for a better life and raising their human dignity. As for ourselves, forming trade unions, leading strikes, organizing demonstrations, issuing underground literature, going to prison made us feel important and self-assertive." 8

The radicalization of Jewish youth who sought equal civil rights in the 1880 s and 1890 s was part of the broad and varied movement for democratic and political reforms in the Russian Empire. By the time of the 1905 Revolution the tone had changed from political reform to liberation through revolution, particularly from the youth who had no memory of the government repression against Jews following the revolts and pogroms in 1881. After visiting Russia in 1903 Zionist leader Chaim Weizman expressed concern that "almost all those now being victimized [by the police] in the entire Social Democratic movement are Jews and their numbers grow everyday.... Almost all students belong to the revolutionary camp; hardly any of them escape its ultimate fate." Alexander Trachtenberg joined the reform movement while 
attending the University of Odessa School of Electrotechnique as an engineering student from 1902 to 1904 , but his education was cut short when Russia's war with Japan forced him into the army. ${ }^{10} \mathrm{He}$ became a war hero and earned the Cross of the Order of St. George, "the highest award for heroic service".11 Most Jewish soldiers at the time could not rise above the rank of corporal. Trachtenberg, however, reportedly ended the war as a captain. Despite his military success, Trachtenberg's war experience only convinced him that militarism and war were products of capitalist oppression. When he rejoined the reform movement after his return home in the late summer of 1905, his activities led to his arrest and imprisonment for about a year.

The Russian Revolution of 1905, led by various revolutionary forces in Russia, was a response to the government's poor handling of the war and a history of political repression. With Jews well represented in the reform movement, economic and social upheavals provided fertile ground for scapegoating. Violent expressions of anti-Semitism in the form of pogroms against Jewish communities took place in 1905 and 1906. An estimated 800 Jews were murdered on 18 October 1905 in Odessa. ${ }^{12}$ The violence and repression against reformers added to the mass exodus of hundreds of thousands of Jews from the Russian Empire during the early twentieth century. When Trachtenberg emerged from prison in 1906, he joined the huge wave of emigrants leaving for America. He left behind a family that included his parents, one brother, and two sisters. On 10 August 1906 he arrived in the United States aboard a ship from Hamburg.

Trachtenberg was among the immigrants arriving from the Russian Empire who brought with them various strains of socialist philosophy. Many Jewish socialists rejected the life of Jewish isolation that they experienced in Russia in favor of a modern scientific education and they rebelled against religion, traditions, and nationalism. They envisioned a united mankind, or internationalism, that influenced their social and political perspective on the world. The immigrants with strong socialist ideas viewed the United States as a symbol of liberation and a country that stood at the forefront of the transition from capitalism to socialism. The American "melting pot" conformed to their ideas on the "historical inevitability" of proletarian equality, and they believed Americanization was an important stage in this process. ${ }^{13}$ Many socialists from Russia and other countries of Europe, including Finland, Poland, and Hungary became part of the growing socialist movement in the United States from the late nineteenth century through the presidential election of 1912, when the Socialist Party reached the height of its national appeal. They joined the struggle against an industrial environment that resisted labor's demands for reforms, such as improved working conditions, fair wages, unemployment insurance, and restrictions against child labor. The more left wing among them opposed reforming capitalism in favor of revolutionary socialism that includ- 
ed public ownership of land and the means of production. The new European members of the Socialist Party contributed to the party majority of non-English speakers and further splintered the party into language federations.

Trachtenberg, who stood five feet three inches with a stocky frame, dark complexion and black hair, a receding hairline, and a full mustache, ${ }^{14}$ exemplified the committed socialist wanting to take advantage of American freedoms while working towards a socialist society. Within three years of his arrival he resumed his education. With the benefit of full academic scholarships, he completed a bachelors degree from Trinity College in Hartford, Connecticut in 1911 followed by graduate studies at Yale University where he completed an MA in education in 1912. He continued at Yale for another three years with the goal of earning a PhD in economics, and although he wrote a dissertation, he left school in 1915 without completing the degree. ${ }^{15}$ As a student from 1909 until 1915, Trachtenberg developed his organizational skills as a leader of student socialist activities, particularly as president of the Yale chapter of the Intercollegiate Socialist Society (ISS), a national organization of affiliated college socialist clubs founded in New York in 1905. Trachtenberg highlighted the success of the organization at the society's national convention in December 1913 when he told ISS representatives that "the Yale Chapter has become influential enough to induce the university to list a course of Socialism, to compel the library to purchase over 300 Socialist books, [and] to out vie every other non-athletic student organization."16

Beginning in 1914 and throughout World War I, Trachtenberg, like many other socialists, placed himself at the forefront of efforts against war, militarism, and military preparedness. He did not see himself as a pacifist; he opposed specifically capitalist wars. He participated in the organization of the Collegiate Anti-Militarism League in 1915 at Columbia University, served as its treasurer, and helped write and distribute an antiwar petition that the organization sent to President Wilson after the sinking of the Lusitania on 7 May. Some of the students at Yale criticized the petition as "underhanded socialist propaganda." Trachtenberg ridiculed critics in a letter to the Yale Daily News as "those who clamored that public schools, income tax, parcel post, woman suffrage and even automobiles and flying machines were socialism in disguise...."17 Despite his efforts Trachtenberg knew that a growing majority of American students agreed with military preparation for war. After the United States entered the war on 6 April 1917, the pressure of American patriotic rhetoric and calls for support of American soldiers gradually weakened the antiwar stance of moderate and right-wing Socialist Party members. The war created a permanent, wide split between left and right wings. Trachtenberg's views did not change, but he avoided the fate of many socialists, including socialist icon Eugene Debs, who landed in jail after criticizing the war effort in violation of the Espionage Act of 1917.18 
After Trachtenberg left Yale in 1915, he worked as an administrator and teacher of economics and labor at the Rand School of Social Sciences in New York. The Rand School, founded in 1906, sought to educate the working class in socialist theory and create political awareness among workers. The promotion of socialism made the school a target for government repression during the Palmer Raids, led by US Attorney General A. Mitchell Palmer, from 1919 to 1920. ${ }^{19}$ At the Rand School Trachtenberg established a labor library in February 1918 that later became the Tamiment Institute Library at New York University, ${ }^{20}$ and he directed the Rand School's Department of Labor Research, which conducted studies for other organizations and gathered and published labor statistics. He edited various Rand publications, including the first four volumes of the American Labor Year Book from 1916 to 1921/22 that provided facts and statistics on the socialist and labor movement in the United States and abroad.

At the time of the Russian Revolution in 1917 Trachtenberg held a moderate left-wing position in the Socialist Party. He worked closely with the centrist party leader and attorney Morris Hillquit, who was reviled by the radical left, and managed Hillquit's campaigns for public office in New York City in 1916 and 1917.21 He still associated with the moderate, Intercollegiate Socialist Society and the Rand School. When the Tsar fell from power in Russia, he supported the social democratic emphasis of Alexander Kerensky's government. After growing weary of Kerensky's failings, he told a gathering of students at a convention of the Intercollegiate Socialist Society in September 1917 that the Russian people wanted socialists in control because they would favor a "radical democratic program" including land confiscation, nationalization, and democratization of industries and institutions, minimum wage, and heavy income tax. ${ }^{22}$ Trachtenberg celebrated the Bolshevik Revolution in October, although he did not truly identify with the Bolsheviks. In an article published in The World in late December, the editor introduced him as a former Menshevik who opposed the ongoing world war but did not support a separate Russian peace. ${ }^{23}$ He refused to join the radical left wing of the Socialist Party that called for immediate revolution in America using precisely the same methods and theoretical bases as the Russian Bolsheviks. Instead, he supported socialist revolution based on recognizing the entrenched power of capitalism and electoral politics in America and developing aggressive Socialist Party strategies to create a revolutionary socialist society. The conflict with the radicals was not so much with the ultimate goal, socialism, but the path to reach it in the American environment. ${ }^{24}$

Despite his caution immediately after the Bolshevik victory in Russia, Trachtenberg publicly embraced the Bolshevik Revolution in order to counter any chance of middle-class-dilution of revolutionary change as he believed occurred in 1905. He fully supported the revolution in speeches, in published 
articles, and in efforts to persuade the United States to cease aggressive action against the Soviet Union. At the second annual celebration of the revolution by the New York chapter of the Socialist Party on 7 November 1919, he pointed out that the significance of the revolution for Americans was that they could achieve the same revolutionary changes only through the large-scale political and economic organization of workers. Through unity and class consciousness, workers would "not only understand their immediate conditions, not only their immediate requirements, but understand the great purpose of an organized labor movement.... Then we can have not only a Soviet Russia, but a Soviet government in England, Germany, and a Soviet America, just as well."25

In May 1919 when moderate Socialist Party leaders expelled the radical, pro-Bolshevik left wing due to irreconcilable differences, two-thirds of the party, mainly consisting of federations of former immigrants organized by their native languages and led by the self-styled leadership of the Russians, eventually formed two main communist groups. The two groups included the Communist Party of America, the largest group consisting almost completely of foreign language speakers, and the Communist Labor Party, comprised of mainly English speakers. Both became underground organizations to avoid the government crackdown on radicals and to follow the Soviet example. ${ }^{26}$ The split among the communist groups was based on language and cultural differences, and the English speakers placed greater emphasis on a strategy for revolution that recognized the differences between the American and Russian political and economic environments. Both parties sought recognition from the Third International or Communist International (Comintern), formed in March 1919 by the Bolshevik regime to direct international communist revolutions and set goals for international communist parties to meet before they would be recognized.

The breakup in the Socialist Party caused membership to shrink from 104,822 in 1919 to 26,766 in $1920 .{ }^{27}$ Trachtenberg and other left-wing members who stayed with the Socialists rejected some of the demands of the Comintern for underground parties fighting for immediate socialist revolution. They believed that the American environment was not ready for communist parties to be successful and supported open organizations that would seek public support. Trachtenberg hoped that the remaining members of the Socialist Party, now decidedly centrist and right wing, could be won over as a revolutionary socialist organization. In general, Trachtenberg's ideological stand illustrated the influence of Americanization and his professional associations with moderate socialist groups that operated in public view, including the Rand School and, beginning in June 1920, the International Ladies Garment Workers Union which hired him as an economist. ${ }^{28}$

Trachtenberg paid a price for his moderate revolutionary politics. In April 1919, prior to splitting from the Socialist Party, the radical left-wing faction 
dominated by English speakers used their periodical, Revolutionary Age, to criticize the moderates in the party as an "insidious enemy of revolutionary socialism."29 In late May editor Louis Fraina, quoting from his public debate with moderate Algernon Lee, criticized Trachtenberg as one of the party members who initially refused to support Lenin and Trotsky. Trachtenberg only defended the Bolsheviks after they took power, argued Fraina, and he challenged Trachtenberg to prove otherwise. ${ }^{30}$ The communist factions that formed and splintered during the summer of 1919, evolved into separate parties in September, and maintained a drumbeat of criticism of the new left wing of the Socialist Party that supported Bolshevism in Russia, but opposed its methods as unsuitable to bring revolutionary socialism to the United States. Also, a majority of the Socialist Party opposed the party's remaining left-wing members' push for political and social revolution. Historian Theodore Draper described Trachtenberg's position as a middle ground that made him "an object of suspicion from both sides of the New York barricades." 31

Trachtenberg and other members of the new left wing that comprised about one-third of the remaining Socialist Party sought to generate a tide of public support for the Soviet Union that included pressing for American recognition of the new government, achieved in 1933. They fought against US and allied military intervention, and the new left wing pushed the Socialist Party to gain the support of the Comintern. Perhaps leaders of the new left wing in the party thought that Soviet recognition of the Socialist Party would illustrate the party's endorsement of revolutionary socialism in Russia and also gain prestige and much needed support for the party, but in retrospect Comintern recognition was unrealistic. Even the party's left wing did not support the entire Soviet program and methodology, but they believed Russia was "doing something which is really challenging world imperialism" and strengthening the proletarian movement. ${ }^{32}$ Trachtenberg urged Socialist Party leaders to apply for recognition by the Comintern, and when they did in March 1920 their application was bitterly rejected with a response describing the Socialists as "traitors to the working class, who on the eve of the World Revolution, sold out to the enemy to save your skins." 33 Trachtenberg eventually realized that the remnants of the Socialist Party could not be transformed as a revolutionary party. The problem, Trachtenberg explained in the December 1921 issue of Workers Council, is that the anti-capitalist, socialist revolutionaries in the Socialist Party clashed with "middle class social reformers" who maintained support for capitalism but did not have the option of joining a European-style liberal party in the United States. The Socialist Party attracted such a wide range of people with differing ideologies that a general acceptance of revolutionary socialism was impossible. "Instead of revolutionary Socialist propaganda and participation in the struggles of the workers, vote catching became the alpha and omega of the party's activity." 34 


\section{$92 \quad$ Lincove}

By the spring of 1921 Trachtenberg, still director of the Department of Labor Research at the Rand School, joined with some members of the Jewish Federation remaining in the Socialist Party to form the Committee for the Third International, also known as the Workers Council. His colleagues in this endeavor included Louis Engdahl, Socialist Party publications editor; William Kruse, head of the Young People's Socialist League; J. B. Salutsky, editor of the Yiddish weekly Naye Welt; Moissaye J. Olgin, a writer who would become editor of the Jewish communist newspaper, Freiheit, founded in 1922; and Benjamin Glassberg, a New York City schoolteacher. The Workers Council sought Socialist Party affiliation with the Comintern, but when the Jewish Federation pulled out of the party in September, the Council also broke away and Trachtenberg resigned from the Rand School because of its close ties to the Socialist Party. They published their own biweekly newspaper, Workers Council, which ran from April to December 1921, in which they expressed intense criticism of the Socialist Party for its lack of revolutionary zeal, and the communist organizations for their rush to form underground organizations and push for violent or immediate revolution, without regard for American political and economic realities.

By the end of 1921 the Workers Council changed its strategy and entered into negotiation for greater unity among communist factions to form a new, above ground, legal organization, the Workers Party of America, which eventually took the name Communist Party of the United States. Negotiations for unity occurred because the Comintern turned away from demands for immediate revolution throughout the world in favor of unifying the various communist parties in each country and forming legal, open communist organizations - a crucial issue for the Workers Council. The Comintern emphasized unity and expanding power through a "unified front" within communist parties and between communist and workers' parties. The new strategy for the communist movement was based on the Comintern's acceptance of the realities of failed revolutions in Europe and the strength of capitalism in the United States. In the spring of 1922 the Comintern confirmed its changed perspective by calling on communist parties to operate openly, tone down international revolutionary rhetoric, encourage participation in electoral campaigns and mainstream unions, and stress local issues that needed immediate reform. ${ }^{35}$ Even after the formation of the Workers Party an illegal underground faction persisted and considered the new organization merely a public front controlled from below. The continuing power struggle included members from the former underground organizations and the so-called centrists or right-wing members of the new party, including Trachtenberg and others from the Workers Council. Trachtenberg originally joined with the communists when it became clear that the Comintern called for ideological reforms that appealed to him, but by mid- 
1923 extremists dominated, and he and the centrists either accepted their leadership or resigned. ${ }^{36}$

Trachtenberg never left the CPUS, and he served it in various influential roles throughout the rest of his life. As a founding member of the CPUS and a respected theoretician, educator, and former Russian revolutionary he participated in the party's highest councils. His colleagues in the party viewed him as having great energy and enthusiasm, high intelligence, a sense of humor, and enough flexibility to respect non-party intellectuals. They remembered him for his ability to listen and for his paternal style of leadership. ${ }^{37}$ As one who survived war and revolution in Russia and successfully adjusted to a new environment in America, Trachtenberg showed similar instincts for flexibility and survival in the party. Melech Epstein, a party member during the 1920 s, referred to him as "agile enough to make the jump from a Centrist of the Workers Council to a loyal and valuable man of the majority camp [in the Workers Party], and to maintain his position after the minority [led by Jay Lovestone] won out, without being hurt in any way."38

There is some evidence that Trachtenberg supported the party leadership of Lovestone over William Foster. Lovestone's alliance with party leader Charles Ruthenberg against rivals Foster and James Cannon mirrored the factional struggle in the Soviet Union following Lenin's death on 21 January 1924. The American factions sought the support of the leadership in the Soviet Union, but the changing nature of the infighting in the Communist Party of the Soviet Union led to turmoil in the Workers Party. After Ruthenberg died on 3 March 1927, Lovestone led the party based on the support he received from Ruthenberg and communications from the Comintern. Lovestone supported the Stalin/Bukharin faction, but when Stalin switched to a left-wing position to out-maneuver and eliminate the power of Bukharin, Lovestone maintained support for his friend Bukharin because he seemed to appreciate the realities of American society. Lovestone's principled support for Bukharin, his open opposition to Stalin, and the resentment against the Comintern's attempts to influence the CPUS led to his downfall in 1929. ${ }^{39}$ Stalin ordered the elimination of Lovestone and his followers from the party. At the time of the struggle for power within the CPUS, Sydney Hook happened to speak with Trachtenberg in Berlin as he traveled with associates to Moscow. Hook remembered, "they had been in a mood of exultant expectation that the Lovestone leadership of the American Party would be sustained."40 Although Trachtenberg may have supported Lovestone based on his pragmatic view that the CPUS should plan its tactics by keeping in mind the realities of American society, it is unlikely that he expressed this view publicly at party meetings. When Foster took over the leadership of the party, Trachtenberg accepted the change and the party's subservience to Stalin's rapidly growing power. His flexibility showed that he focused on creating a revolutionary, socialist society 
in the United States and maintaining a strong Soviet Union. As he worked toward these two goals, he adjusted to the Soviet's shifting internal politics and foreign policy.

Trachtenberg became a member of the party's first Central Executive Committee, an administrator and teacher in the party-sponsored Worker School in New York City, a frequent writer in communist periodicals, newspapers and books, an electoral campaign director for Communist Party candidates, and even a candidate himself, including runs for the US Senate in 1922 and Borough President of Manhattan in 1925.41 As a leader in the party he frequently traveled to Europe and the Soviet Union as its representative at international party conferences and to confer with communist leaders in other countries. For example, Trachtenberg was out of the country for 14 months to serve as a delegate at the Fourth Congress of the Comintern in November 1922 and to engage in various discussions with Soviet Party leaders. During this trip, which lasted until December 1923, he visited Czechoslovakia, Germany, France, and Austria. After returning home the party sent him on a national tour to communicate his experiences and thoughts about conditions in the Soviet Union and the status of revolutionary movements in other countries. Recently declassified documents from Trachtenberg's FBI file reveal that local agents attended his presentations to gather information and detect any illegal statements that might lead to an indictment under federal law. No such statements were ever detected. On one occasion an agent in Minneapolis fell asleep less than fifteen minutes after Trachtenberg began to talk, leading his superior to report him to FBI headquarters and complain that "this incident struck me as typical of the attitude of the Department of Justice and, unfortunately, of Americans generally, who choose for their sleeping hour the hour when the enemy is awake and busiest." 42

Trachtenberg's most influential contributions to the communist movement included his leadership of the Communist Party's cultural apparatus and the publication and distribution of communist literature. When Trachtenberg founded International Publishers in 1924, he created for himself a livelihood that followed his interest in education and publishing revolutionary literature that began at the Rand School. His work meshed quite well with his dedicated efforts at the highest levels of the CPUS in its struggle to end capitalism and create a revolutionary socialist society in the United States. International Publishers was not just a business enterprise, but was also a means to educate Americans in Marxist-Leninist teachings and bring them under the influence of the CPUS. When Trachtenberg started organizing the business in June 1924, he wrote to Nicholas Dozenberg, head of the Workers Party Literature Department, requesting a list of radical bookshops in the United States for a possible survey of interest in translated classical texts on socialism. He asked for Dozenberg's opinion about his publishing project and explained, "there are 
a great many good books which should be brought out in the English language. They will prove of great value to our movement." 43 In October Trachtenberg communicated with Charles Ruthenberg, the Party's Executive Secretary, to assure the party leader that International Publishers did not seek to compete with the publication program of the party but to offer help and cooperation with it by publishing "special and cheaper editions of such books under the party's imprint and for its own distribution. This firm is, of course, also planning to bring out books of a literary character and of general academic interest which the party would not be interested in." 44 By offering a broad array of publications and attempting to appeal not only to the worker class but also to progressives among general and scholarly readers, Trachtenberg wanted to establish a publishing firm that would be independent of the party while working with it and remaining consistent with party ideology.

There were other publishers of socialist literature apart from communist organizations, such as Vanguard Press founded in 1926 and Charles H. Kerr founded in 1886, but International Publishers developed into a more systematic source of radical literature and propaganda consistent with Lenin's concept of combining ideas and action to influence the masses. ${ }^{45}$ A commentator writing in the Daily Worker in 1964 observed that Trachtenberg not only sought to fill a gap neglected by Charles H. Kerr by "propagating the theoretical and historical works of Marx and Engels" among American workers, he also sought to publish books about the integration of Marxist ideology in society as illustrated in literature, history, and the social sciences. ${ }^{46}$ Kerr did publish translations of classical texts of Marxism, but the federal government's aggressive use of the Espionage Act of 1917 severely weakened the company by limiting its ability to use the postal service to mail periodicals and books sympathetic to socialism or communism. Kerr also suffered from the fragmentation of the socialist movement beginning in 1919, postwar government repression against the left, and other political changes in the 1920s that eliminated a large portion of its market. ${ }^{47}$ Also, unlike other left-wing book publishers at the time of its founding, International Publishers quickly became identified with the CPUS even though the party also developed its own book and periodical publishing apparatus in the form of Workers Library Publishers from its incorporation in March 1928 until 1945 when New Century Publishers took its place. In later decades other independent radical and left-wing publishers appeared, such as the Monthly Review Press that began in 1951 in New York as the publishing arm of the periodical Monthly Review, and Verso started in London in 1970 by New Left Review. Both publishers identified with the New Left movement of the early Cold War years and focused on a range of issues including support for civil rights, third world development, human rights, and the environment. Despite the competition, International Publishers persisted through the years as it maintained a series of classical texts and published a diversified catalog of 
reprints and new titles of history, politics, contemporary issues, fiction, science, and art.

Trachtenberg founded International Publishers in New York City with the financial backing of a wealthy friend, Abraham A. Heller, known to critics as the "millionaire Bolshevist" or "millionaire red," who contributed to various socialist and communist causes. Heller, born in Russia in 1874, came to the United States in 1891 and by 1924 he had earned a fortune in the manufacture of synthetic jewelry and pressurized oxygen for use in acetylene welding. He invested between $\$ 110,000$ and $\$ 115,000$ in support of International Publishers during its first fifteen years. At the time of original incorporation on 17 July 1924 the name of the company was International Publishers \& Booksellers Inc., and there were five directors, three of whom owned equal shares of stock. At the first meeting on 22 July the directors approved a resolution proposed by Trachtenberg, who was not a director, to transfer to him and his nominee, 750 shares of common stock carrying no monetary value. The three shareholders, Russell F. Thomas (president), M. B. Massberg, and A. Phillips immediately transferred their shares to Heller and Trachtenberg for the price of one dollar, and on the same day, all five directors resigned. On 25 July Heller and Trachtenberg split the stock three ways by adding Heller's wife Edith as an equal shareholder. Heller became president, Edith secretary, and Trachtenberg treasurer. Later Edith would split her shares between her husband and Trachtenberg making them equal holders of company stock. On 26 December 1924 they changed the company name to International Publishers Co., Inc. ${ }^{48}$ Although Heller provided financial support and covered the firm's debts, he left the daily operation of the business to Trachtenberg who not only served as treasurer but also manager, editor, salesman, and, eventually, secretary. ${ }^{49}$

Trachtenberg's testimony before the House of Representatives Special Committee on Un-American Activities (HUAC) in September 1939 reveals important details about the operation of International Publishers. ${ }^{50}$ The hearings, chaired by Republican Congressman Martin Dies of Texas beginning in 1938, proposed to investigate mainly Nazi, fascist, and communist propaganda activities in the United States at a time when the amount of propaganda material opposing capitalism and American democracy had grown tremendously. The committee wanted to reveal who was involved, how the propaganda was created and distributed, and examples of propaganda publications. Also, Dies sought to use the committee as an attack on what he and other conservatives saw as the left-wing policies and "creeping totalitarianism" of the Roosevelt Administration..$^{51}$ In Trachtenberg's case the committee wanted to learn whether International Publishers associated directly with the communist parties in both the United States and the Soviet Union and to find out whether he followed directives and received funding from communists. In his testimony Trachtenberg did not hide his personal support for Comintern ideology, and he 
openly stated that International Publishers' principle goal was to publish materials that followed the Soviet line of ideology and contributed to the communist movement. ${ }^{52}$

In his testimony on 13 September 1939 Trachtenberg gave an indication of International Publishers' revenues, production, and sales strategy. Gross sales in recent years ranged from $\$ 75,000$ to $\$ 80,000$ per year with prices ranging from less than one dollar for pamphlets to three dollars for books. The annual sales figures compare with figures found in his papers for the first several years of operation when sales rose from $\$ 10,946$ in 1925 to $\$ 42,135$ in 1933 . The onset of the Depression led to erratic performance after 1929 with 1931 being the best performing year at $\$ 43,335$ during the first nine years. His main expenses included the production and printing of books, wages for four employees, book promotion, commissions, and taxes. He cited his own salary in the range of $\$ 40$ to $\$ 75$ per week. Apparently he paid little in royalties for the publication of translated works by Russian authors because, he noted, there was no copyright agreement between the United States and the Soviet Union. Although he paid several hundred dollars of royalties to Georgi Dimitrov for The United Front: The Struggle Against Fascism and War (1938), Stalin received no royalties for the sale of his works. ${ }^{53}$

Approximately ten percent of International Publishers' revenue came from purchasing and reselling 500-1,000 copies of titles produced by publishers in other countries. Only when he believed he could sell at least 3,000 copies of a title would Trachtenberg consider publication by his firm. He testified that among the titles produced by International Publishers, 80 percent of the copies printed were exported to locations outside of the United States, and 80 percent of the exports were sent to the Soviet Union. The basis for such a large volume of exports outside of the United States would likely be the much greater interest in socialism in Europe and apparently English language publications were in demand. That 80 percent of the exports went to the Soviet Union reflected the needs of foreign students attending special schools devoted to teaching socialism and the interests of foreign visitors who would purchase books in bookstores. Within the United States, International Publishers also sold directly to mainstream bookstores, universities, libraries, schools, and 4050 communist bookshops throughout the country. At least half of the domestic sales were in New York State and distributed by the Wholesale Book Corporation. Trachtenberg also maintained close relationships with book publishers and distributors in England and the Soviet Union, including Lawrence \& Wishart and Allen \& Unwin in London, and the Foreign Languages Publishing House and the Cooperative Publishing Society of Foreign Workers in Moscow. The foreign contacts provided a way for the company to sell books abroad but also served as an important source for manuscripts that could be 
published for the first time or simultaneously in the United States and in other countries. $^{54}$

At the 1939 Congressional hearing Trachtenberg characterized the relationship between International Publishers and the CPUS as a business relationship between his firm and a party subsidiary called Workers Library Publishers that acted as the party's mechanism for publishing and distributing books, pamphlets, periodicals, and newspapers throughout the United States. Workers Library frequently took International Publishers' books on consignment to sell in bookshops run by local party leaders in various cities throughout the country. ${ }^{55}$ Despite his claim that International Publishers acted independently from the CPUS, Trachtenberg's testimony showed that his work for the party and the publishing firm blurred the lines between International Publishers and Workers Library Publishers. From the early days of International Publishers in 1924 he sought a close relationship with the party through its literature department. ${ }^{56}$ In March 1928 he served as one of five directors of Workers Library Publishers at the time of its incorporation. ${ }^{57}$ By 1939 his involvement with both publishing operations was based on his service as chair or as leader of the party's national literature committee during the late 1920s through the 1940s. According to the party's financial secretary, William Weiner, the literature committee had direct influence on publishing for Workers Library Publishers. Trachtenberg's relationship with both publishers was so close that most writers about the communist movement, including party members, described International Publishers as the party's publishing house. Trachtenberg resented such statements even when they appeared in the party's literary journal, New Masses. ${ }^{58}$ He vigorously pursued the distribution of propaganda as a responsibility of party leadership, but as a publisher he attempted to distinguish between his firm's publications for propaganda and education. ${ }^{59}$ Given the integration of his publishing and party activities, such a distinction appears disingenuous, because he sought to persuade readers to join the cause of the CPUS and to form an idealized view of the Soviet Union despite the Soviet's repressive regime and export of propaganda to Europe and the United States.

International Publishers and Workers Library Publishers produced inexpensive pamphlets to distribute or sell to existing and prospective members of the CPUS, particularly in labor unions or industries that were not yet unionized. Party Organizer, the party's periodical for maintaining control and direction over party affiliates nationwide, published detailed, instructive articles about distributing literature in various settings and party gatherings that urged the participation of the entire membership. The CPUS also encouraged the organization of study groups and reading circles to circulate literature and promote better understanding of Marxist/Leninist ideology. Even bookmobiles were considered a creative approach to getting the party's publications in the 
hands of Americans. ${ }^{60}$ Since Workers Library Publishers often marketed and sold literature from International Publishers, the party's program of literature distribution applied to the publications of both publishers. As a leader in the literature department of the party, Trachtenberg contributed to articles in Party Organizer, including a speech at the party's tenth national convention in New York in May 1938. He emphasized that "we cannot build a mass Communist Party unless we use one of our best weapons - literature. We cannot reach the masses in America without the agitational and propaganda literature of our party." He stressed the importance of distributing greater amounts of literature and updating methods of distribution as the demand for the party's theoretical literature increased. Literature directors needed to look beyond the big urban areas to "the thousands of small industrial and village towns where our literature departments have not penetrated at all. If we are going to reach millions, we must provide literature to these great communities throughout America." 61

During the Dies Committee hearings Trachtenberg denied any ties between International Publishers and the Comintern, but research based on documents in the Russian archives opened after the fall of the Soviet Union revealed that the company received funding from the Comintern either directly or indirectly through the CPUS. ${ }^{62}$ Another clear indication of Trachtenberg's reliance on the Comintern or the Communist Party in the Soviet Union involved the care he took when choosing manuscripts for publication. An example is the case of writer Scott Nearing, a long time friend from the Rand School who joined the party in 1927. Nearing submitted a manuscript to International Publishers in 1929 on the subject of imperialism, but Trachtenberg suspected an ideological problem and sent the manuscript to the party leadership in Moscow for approval. When the authorities in Moscow rejected Nearing's manuscript because it deviated from Stalinist interpretations of Lenin's ideology, Trachtenberg seemed apologetic when he told Nearing that he would like to publish his book but "over there they are more interested in party politics than they are in social theory." 63

Nearing promptly resigned from the CPUS, and published his book, Twilight of Empire, with Vanguard Press in 1930. He still respected and supported the Communist Party, but biographer John Saltmarsh notes that he was much too independent a thinker to bend to the party's will. The incident illustrated that writers in the movement for revolutionary socialism were under pressure to discipline themselves according to Marxist ideology, and accept party decisions and ideological dictates from authorities in the Soviet Union. The party expected professional revolutionaries to give their lives to the fight for the interests of their class without regard to family or the difficulties they would encounter. ${ }^{64}$ Anna Rochester, a socialist writer and activist for women's rights, clarified the struggles experienced by writers in the party, albeit in a 
more positive way. Writing to Trachtenberg on the tenth anniversary of International Publishers in 1934, she complimented his skill to work with "half-ripe writers" seeking their ultimate goal of "...Bolshevik wisdom! But I am a lot nearer to being really useful to the movement than I could ever have become without your reasonable patient and intelligent political criticism.... It is not so easy to guard the 'line' without discouraging the new recruit. Here's hoping your work will continue until you can have a real old age in Soviet America." $" 65$

The Soviet Union clarified the responsibilities of writers in the communist movement at the Second World Plenum of the International Bureau of Revolutionary Literature held in Kharkov from 6-15 November 1930. The Comintern instructed the CPUS to enlist writers into their ranks to work for the revolution. John Reed Clubs, which were initiated in November 1929 by the editors of New Masses and spread nationwide to encourage young writers and artists to participate in the revolutionary socialist movement, were told to put more effort into working within the black community, increase contacts with workers, and pay more attention to Marxist literary criticism. For its part the monthly periodical New Masses, which began in 1926, was "instructed to make itself "in every respect the cultural organ of the class-conscious workers and revolutionary intellectuals of the country." These policies would not preclude encouraging writers who could not accept all the precepts of the communist movement, because they could be educated, but eventually they had to discipline themselves to follow party ideology. ${ }^{66}$

New Masses ceased as a monthly in September 1933 and reappeared as a weekly in 1934. It sought new and established writers of poetry, fiction, and essays that merged art and politics by depicting the condition and strivings of workers. In the 1930s editors and writers for New Masses, such as Walt Carmon, Stanley Burnshaw, Mike Gold, Joseph Freeman, and Granville Hicks may have felt free to write without party scrutiny or political pressure, but under Trachtenberg's direction as the party's cultural director, communist influence at the magazine steadily increased with the party's control over the membership of the editorial board. Trachtenberg believed that writers should have leeway, but also agreed with the party's expectations that writers should understand enough of the party's ideology to write literature consistent with the movement. For example, historian Alan Wald describes Burnshaw, a poet who worked full time for New Masses from 1933 to 1936 while never joining the CPUS, as "unequivocally part of the institutionalized leadership of a 'movement' bound together by a common worldview ... [and as having] a set of propositions that were the equivalent of a Communist outlook." 67 Similarly, Hicks, who became editor in 1934 and led the magazine to new heights of circulation during the Popular Front, saw a need for writers to be disciplined by Marxism and take part in the class struggle so that they could "destroy the 
innumerable survivals of their bourgeois inheritance."68 On the other hand, writers that misinterpreted or deviated from party ideology would not be tolerated as Freeman experienced when Trachtenberg publicly rebuked him at a party meeting as "a rotten liberal" for his literary activities and opinions. ${ }^{69}$

International Publishers usually offered books and pamphlets with a utilitarian, academic, or inexpensive format, but sometimes illustrations reinforced proletarian themes. Color images appeared on book covers, and occasionally the publisher added interior photographs or artistic drawings and illustrations by artists such as William Siegel, Hugo Gellert, and Esther Shemitz. The hardback series of classical translations, such as the Marxist Library and the works of Lenin, were designed for libraries and schools that could pay for larger, more elaborate publications. Whether paperback or hardback, most volumes printed or engraved the publisher's distinctive logo depicting an upright, shirtless laborer grasping an oversized book, thus emphasizing the importance of books and ideas in the class struggle.

The publication program of International Publishers followed the Communist Party line by adjusting to political and ideological changes as announced by the Comintern. From 1924 through the 1930s, Soviet policy shifted dramatically on several occasions as Stalin took authoritarian control of the Soviet Union and Russian nationalism became important in the preservation of Soviet rule and Stalin's personal power. The changes caused International Publishers to avoid authors whose ideas the party rejected. In the case of Nikolai Bukharin, Stalin's close ally against competing factions, a leader in the Comintern, and editor of Pravda, the firm published his Economic History of the Leisure Classes (1927) and Imperialism and the World Economy (1929). During the late 1920s and the 1930s, he gradually lost influence as Stalin's politics shifted to the left, and in March 1938 Bukharin was tried and executed amid Stalin's Great Purge of party leaders and millions of other Russians considered a threat to his power. International Publishers also published three works by Leon Trotsky during 1925 and 1926, including Literature and Revolution (1925), but Trotsky, who became Stalin's archrival for power after Lenin died in 1924, was expelled from the party in 1927 and assassinated in Mexico on 20 August 1940. After the Communist Party forced both men out, Trachtenberg would not publish any more of their writings, or the works of authors who sympathized with them. In his 1939 Congressional testimony, Trachtenberg explained that while he would sell a requested copy of Bukharin's works that he stored in his warehouse, the buyers would either be Trotsky sympathizers or the party's worker schools that used the texts in classes in order to refute them. ${ }^{70}$

From the beginning of International Publishers Trachtenberg emphasized publishing English translations of revolutionary writings, speeches, and corre- 
spondences of the fathers of socialism and communism, particularly Marx, Engels, Lenin, and Stalin. Lenin's writings were published in series of multivolume paperback and hardback editions. ${ }^{71}$ There were few English translations of these fundamental works and Trachtenberg set out to provide them in a series of hardback and cheap paperback editions that workers could afford. For example, he published Correspondence, 1846-1895 (1934) by Karl Marx and Friedrich Engels; Little Lenin Library, a selection of Lenin's writings in 36 pamphlets that appeared from 1929 to 1953; The Russian Revolution (1938) by Lenin and Stalin; Leninism (1933), a two volume collection of Stalin's writings; and 37 volumes from various authors in the Marxist Library series published from 1932 to 1940 . Reprints of classical works continued to be an important part of the publication program following World War II with works such as Economic Problems of Socialism in the U.S.S.R. (1952) by Stalin and Marx and Engels on Malthus: Selections (1954). Following Stalin's death in 1953, Trachtenberg did not publish another work by him. Only two works by Stalin have since appeared from International Publishers, Foundations of Leninism (1970) and Dialectical and Historical Materialism (1973). There is no evidence that Trachtenberg deliberately stopped publishing works by Stalin, although Stalin's reputation in the Soviet Union suffered after Nikita Khrushchev publicly criticized him in 1956 for the widespread killing of party members and millions of Russians in the Great Purge of the 1930s. After Trachtenberg's retirement in 1962, the new director of the press, James Allen, continued the tradition of classical reprints with three volumes of Lenin's Selected Works (1967) that appeared in the New World Paperbacks series and also Lenin's The Awakening of Asia: Selected Essays published in 1970. International Publishers put out additional selected works of Marx and Engels, including On Colonialism: Articles From the New York Tribune and Other Writings (1972) and On Historical Materialism: A Collection (1974). In 1975, under the leadership of Lou Diskin, the publisher commenced Karl Marx, Frederick Engels: Collected Works, a series that now includes 49 volumes.

International Publishers brought out books that put Soviet society in a positive light, particularly regarding such issues as the Soviet Union's peaceful nature, economic development, the success of agricultural collectivization in the Five Year Plan that began in 1928, and increasing satisfaction among the masses of workers in the quality of their lives. For example, in Red Villages: The Five Year Plan in Soviet Agriculture (1931) Yakov Yakovlev extols the progress made with introducing advanced equipment and methodologies in collectivized farms, and explains how the Soviet program is superior to American large-scale farming. When the book was published Yakovlev was a Soviet agriculture minister; he was later executed in 1937 as a supporter of Trotsky. ${ }^{72}$ Soviet advantages are further explained in The American Farmer (1932) that focuses on the negative impact of the depression and the domina- 
tion of "rich" farmers over average, small farmers in the United States who only have the Communist-led United Farmers League to count on for support. ${ }^{73}$ Additional examples include Anna Rochester's Why Farmers Are Poor (1940), which illustrates the plight of farmers in a capitalist system, and Joan Beauchamp's Women Who Work, published simultaneously by International Publishers and the British publishing house Lawrence and Wishart in 1937, which compares the superior working conditions for women in the Soviet Union with less desirable conditions in England. In Religion in the USSR (1934) E. Yaroslavsky, a leader in the League of Militant Atheists, argues for the superiority and greater importance of building socialism compared with wasting time on superstition in religion. In wartime the theme of Soviet heroism included a collection of Stalin's speeches after the German invasion, The War of National Liberation (1942), Maurice Dobb's Soviet Planning and Labor in Peace and War (1943) and Harry Ward's The Soviet Spirit (1944).

An important publishing event for International Publishers was the appearance in 1939 of the English translation of History of the Communist Party of the Soviet Union (Bolsheviks) authorized and edited by the Central Committee of the CPSU. The Foreign Language Publishing House in Moscow brought out an English edition simultaneously. Beginning in 1883 with the rise of Marxist groups in Russia and ending in 1937 with the elimination of the "Bukharin-Trotsky Gang," the authors provide a "short course" that praises the development of Soviet communism and clarifies the lessons learned by studying the history of the party. The CPUS and International Publishers planned for a huge printing run of 100,000 copies to coincide with the twentieth anniversary of the Communist International and the early communist parties in the United States. The CPUS agreed to take responsibility for selling and distributing the book to bookstores for one dollar, and made a special edition available to party members and the Young Communist League at the special price of 40 cents. They established distribution quotas for each state and elaborate plans to promote the book through lectures, displays, book reviews, study groups, and a national essay contest on the significance of the book. ${ }^{74}$

Trachtenberg also encouraged and published revolutionary and proletarian fiction, which communists believed was an important tool that could be used to educate the masses about the struggle against capitalism. In fact, in early 1925 the first official publication appearing from International Publishers was a collection of stories written by Soviet authors and translated into English. Flying Osip: Stories of a New Russia introduced stories on post-revolution famine, awakenings of national spirit, devotion to Lenin and communism, and life in communist Russia. Other early translated works of fiction were Dimitry Merezhkovsky's December the Fourteenth (1925) on the unsuccessful uprising against Nicholas I in 1825, and Alexander Fadeev's Nineteen (1929) set in the period of the Russian Revolution. The role of fiction in the communist move- 
ment took on greater importance with the organization in New York of John Reed Clubs that encouraged and disciplined young writers and artists to create "with a social vision" consistent with Stalin's ideology, and to present complex ideas in a simple form to American workers. ${ }^{75}$ International Publishers encouraged this process by putting out translations of V. Ilenkov's Driving Axle: A Novel of Socialist Construction (1933) that emphasized the importance of building the socialist state, and Alexander Serafimovich's The Iron Flood (1935) on the struggle of undisciplined, common soldiers fighting antiBolshevik Cossacks and the building of a new national identity in Russia during the first year after the October Revolution. The deepening Depression in America provided opportunities to use stories like these to motivate workers to take up the communist cause. Trachtenberg believed that such exposure to the Socialist Realism of proletarian literature would create or strengthen workers' emotional attachment to the communist movement.

Trachtenberg offered his own perspective on the term "proletarian literature" when he explained to attendees at the first American Writers Congress in 1935 that "stories of the struggles of the southern sharecroppers, Negro stevedores, coal miners, workers in the mines and mills of the Midwest, in factory and shop throughout the country - such writings have a powerful effect in arousing anger and hatred against capitalism, as well as in indicating the revolutionary road which the working class and its allies must take." ${ }^{96}$ These American themes give the impression that there was a clear national outlook to the writing of radical literature in the United States. In her analysis of proletarian fiction Barbara Foley explains that American proletarian writers were not obligated to follow a rigid Soviet example or even produce works in line with party ideology, and it was common for writers of the 1930s to interpret their work as art distinct from propaganda. She emphasizes, however, that the concept of Socialist Realism "strongly influenced U.S. literary radicalism in all its phases. The Americans' interest in a literature based on factuality and verisimilitude reflected in large part their continuing loyalty to the Proletkult concept - the 'facts, facts, facts' of which [poet] Sergei Tretyakov had written with such enthusiasm." The definition and role of proletarian fiction became a contested issue among writers and literary critics in New Masses and Partisan Review, both coordinated by the Literature Committee of the party. Philip Rahv and William Phillips, editors of Partisan Review, increasingly criticized proletarian literature for its lack of technical and stylistic quality, and they came to see it as practically worthless. Even translated letters written by Marx and Engels to left-wing writers "came to be frequently cited in discussions of 'tendentiousness' and 'propaganda' in proletarian literature." Trachtenberg also believed in well-written literature consistent with party ideology, and he supported the Partisan Review, but this did not stop Rahv and 
Phillips from pulling the periodical out of the party's Stalinist sphere in December 1937 as they turned towards Trotskyism. ${ }^{78}$

By the mid-1930s Stalin responded to the expansion of fascism in Europe with a new policy of the Popular Front officially announced at the Seventh Congress of the Communist International in the summer of 1935. The Popular Front sought to increase flexibility in communist ideology and produce a broad political alliance to fight fascism, promote friendship with the Soviet Union, and direct party members to participate in mainstream labor unions. ${ }^{79}$ This was a radical change from the previous policy of scorning liberal forces as "social fascists." The Popular Front increased party membership in the United States and encouraged the sympathies of increasing numbers of "fellow travelers" who did not join the party but favored social justice, hated fascism, and saw in the communist program possible solutions to American social problems in years of economic and political crisis. The Comintern encouraged the CPUS to work with existing unions and was for Roosevelt's New Deal. This led the party to seek greater integration into American political and labor institutions, and the enhancement of Popular Front cultural and social activities. Michael Denning criticizes the traditional explanation of the Popular Front as a movement based on the political influence of Soviet policy. Denning, instead, focuses on the integration of politics and culture - what he terms the "cultural front" - emphasizing its local origins and pervasive influence on American social and cultural institutions decades beyond the 1930s. Denning interprets the period as the "age of the CIO," when the Congress of Industrial Organizations, founded in 1935 and built with the assistance of American communists, helped infuse a labor culture into mainstream society that competed against the commercial "Advertising Front" in the mass media. The working-class, labor-oriented "cultural front," manifested in the work of a wide variety of "cultural workmen" such as writers, philosophers, musicians, filmmakers, and artists was a phenomenon that represented American cultural expressions with a radical flavor. ${ }^{80}$

The public softening of the Communist Party's approach toward the literary community encouraged efforts to recruit a broad group of writers against the growing power of Nazism in Germany, although party leaders directed the new tactic mainly at prestigious writers who were not necessarily expected to join the party but to lend it greater appeal. ${ }^{81}$ The theme of greater unity underlay the purpose of the first American Writers Congress organized by the Communist Party in May 1935 with Trachtenberg's leadership, after the party eliminated the John Reed Clubs in 1934 as a move toward a stronger Popular Front that included accomplished writers. He and other party cultural leaders, including Joseph Freeman, Michael Gold, and party secretary Earl Browder, carefully invited writers who not only opposed fascism but also recognized the "decay of capitalism, [and] of the inevitability of revolution." ${ }^{\prime 82}$ To lend added 


\section{Lincove}

strength to the theme of unity at the convention, the party organized the League of American Writers. The league initially included writers such as Nelson Algren, Langston Hughes, Kenneth Burke, Erskine Caldwell, and James Farrell. Granville Hicks, who was a prominent Marxist literary critic and editor of New Masses from 1934 to 1939, remembered years later that Trachtenberg and other dedicated communists involved in the league were revered by members as having "access to secrets which were profoundly true as estimates of the correct way of winning support for the fight against fascism and for the defense of the Soviet Union. These fellows who had been in [the movement] ... for years walked in an atmosphere of superior knowledge and understanding and experience. They wore Lenin like a halo."83

International Publishers magnified the broad array of left-wing writers in the mid-1930s with the publication of Proletarian Literature in the United States: An Anthology (1935). Appearing several months after the Writers' Congress, this book provided selections from recent works of fiction by authors such as Erskine Caldwell, Jack Conroy, John Dos Passos, and Tillie Lerner; poetry from Stanley Burnshaw, Horace Gregory, Langston Hughes, and Murial Rukeyser; journalistic reportage from Meridel Le Sueur, Joseph North, and Agnes Smedley; drama from Clifford Odets and John Wexley; and literary criticism from Malcom Cowley, Granville Hicks, Joshua Kunitz, William Phillips, and Philip Rahv. Authors like Burnshaw and Smedley were not party members, but they closely aligned themselves with left-wing or progressive causes that influenced their writing and did not violate party ideology. In the introduction to Proletarian Literature, writer and CPUS member Joseph Freeman defended the merits of left-wing writers and artists who merged politics and art in their work, and argued that bourgeois critics should not label them as propagandists simply because they recognized contemporary social problems. The British writer, Ralph Fox, pursued the same theme in The Novel and the People (1937) in which he held up Marxism and Socialist Realism as tools to "unite and re-vitalise [sic] the forces of the Left in literature" in Britain. ${ }^{84}$ Consistent with the new emphasis on strength through unity, International Publishers provided readers with Richard Wright's Bright and Morning Star (1938), an example of fiction that not only depicted the plight of black workers in the 1930s but also emphasized the theme of unity among black and white workers in the struggle against capitalism. The theme of unity broke down, however, when the League of American Writers lost much of its popularity after the Nazi-Soviet Pact (1939) and the onset of World War II. International Publishers published The Hollow Men (1941), a collection of Michael Gold's essays from the party newspaper, Daily Worker. Gold, who was editor of New Masses, described the growing split among the proletarian writers of the 1930s over issues of war and defense. Using epithets like "rene- 
gades" and "hollow men," he criticized those writers who turned away from the struggle against capitalism and called for war against fascism. ${ }^{85}$

Additional themes in the publishing program of International Publishers through World War II were the plight of workers in America, historical and biographical studies, the African-American struggle for equal civil rights, and issues of peace and war in the United States and Soviet Union. For example, Labor and Silk (1929) was part of the Labor and Industry series published with the Labor Research Association (LRA) that focused on different industries from the perspective of workers and their future under capitalism. The author, Grace Hutchins, called for a program of action against poor working conditions and inadequate worker benefits, and she compared the plight of American workers with counterparts in the Soviet Union. Hutchins explained that silk workers needed militant union organizations that would provide broad, persistent support for their needs. Her book appeared during the time prior to the Popular Front when the CPUS followed the Comintern's directives to encourage labor strikes and make ready for revolution. ${ }^{86}$ Among the series of seven titles published from 1929 to 1940 include Robert W. Dunn's Labor and Automobiles (1929), Anna Rochester's Labor and Coal (1931), and Horace W. Davis's Labor and Steel (1933), all offering interesting, artistic illustrations depicting the plight of industrial workers. These were just a few of the 45 books that the LRA published in association with International Publishers. Trachtenberg helped organize the LRA along with Robert Dunn, Grace Hutchins, and Anna Rochester and together they produced a stream of labor related periodicals and books. They created a long running periodical, Labor Fact Book, which appeared from 1931 to 1965 and served as a continuation of American Labor Year Book that Trachtenberg published with the Rand School.

International Publishers published many books of history and biography that sought to bolster the communist program and serve as educational tools to illustrate the historical explanatory power of Marxist ideology. In 1929 International Publishers published a reprint of Max Beer's 1924 work entitled Social Struggle in the Middle Ages. Beer referred to "medieval communism" and defined it as the "revolt against private property and the temporal power of the Church". He argued, as well, that it provided a renewed focus on social ethics and philosophy, anti-materialism, and spirituality. ${ }^{87}$ In 1927 International Publishers published Eugene Lyon's The Life and Death of Sacco and Vanzetti, a book sympathetic to Nicola Sacco and Bartolomeo Vanzetti, two anarchists convicted of murder in 1921 and eventually executed in 1927. Their case drew worldwide attention and controversy because critics believed the two men were prosecuted for their political beliefs. Trachtenberg wrote The History of May Day (1931), a short, illustrated pamphlet that emphasized the rising strength and solidarity of laborers and their betrayal by the "fascist" American Federation of Labor and Socialist Party. He interpreted the contin- 
uing popularity of May Day as representing the steady decline of capitalism and the inexorable march toward communism in the United States. ${ }^{88}$ Additional examples of historical works are William Siegel's The Paris Commune: A Story in Pictures (1931) about the violent revolutionary activities in the Paris Commune of 1871 that followed the defeat of France in its war with Prussia; James Allen's account of the African-American struggle for freedom and democracy in Reconstruction after the Civil War (1937) in the publisher's History of the American People series; Francis Franklin's The Rise of the American Nation 1789-1824 (1943) that sets out to interpret early American history within a Marxist framework; and Philip Foner's Jews in American History 1654-1865 (1945), a brief examination of American Jews' battle against discrimination and prejudice.

The lives and ideas of key revolutionaries were also important themes in the publishing program of International Publishers. Readers might be inspired to join the communist effort after reading sympathetic and inspirational works about well-known persons in history. In 1929 Bill Haywood's Book provided an autobiography of a dynamic leader of the radical Industrial Workers of the World. In the publisher's series "Voices of Revolt", Trachtenberg published selected speeches of French revolutionaries Jean Marat, Maximilien Robespierre, and Georges Danton, German communist Karl Liebknecht (who was assassinated in Germany's communist revolution after World War I), and Charles Ruthenberg, the first leader of the Workers Party of America. Trachtenberg wrote the introduction to Speeches of Eugene V. Debs (1928), another book from the series. Trachtenberg considered Debs, who ran for president five times on the Socialist Party ticket between 1900 and 1920, a giant among revolutionaries. For socialists and many communists Debs was a revolutionary icon even though he did not join the CPUS. In later years biographies and memoirs of more recent party members appeared, including William Z. Foster: An Appreciation (1955) and Robert Minor: Artist and Crusader (1956), both by Trachtenberg's close friend Joseph North, and Letters From Prison (1956) written by Eugene Dennis.

In the late 1930s and early 1940s International Publishers brought out several books of speeches and writings on noted Americans. The 1937 book Thomas Paine: Selections From His Writings, depicted a key American revolutionary propagandist who advocated independence from Great Britain in Common Sense published in 1776 and supported early phases of the French Revolution. In the introduction, James Allen described Paine as "a bourgeoisdemocratic internationalist" who wrote the manifesto of the American Revolution, represented a challenge to the capitalist society of his day, and should be remembered and revered today by labor as a fighter and hero of democracy. ${ }^{89}$ From the late 1930s to the mid-1940s Philip Foner compiled and edited a series of small collections of writings and speeches by Abraham 
Lincoln, Thomas Jefferson, George Washington, Franklin D. Roosevelt, and Frederick Douglas. All of these works were expected to illustrate the revolutionary nature of key American leaders and enhance bonds of unity between communists and the American mainstream population.

Another important element of Trachtenberg's publishing program centered on books about the plight of African Americans in American society. The Communist Party's attention to the cause of political and social equality for African Americans became a significant part of the party's activities following the Comintern's emphasis on racial issues. This policy, announced at its Sixth World Congress in 1928, sought to call attention to the inequality inherent in capitalism and it became the basis for the CPUS program to recruit members in the black community. For years there were differences of opinion in the party regarding the best path toward full equality. The Comintern's policy rejected the idea of "reformism" supported by the National Association for the Advancement of Colored People (NAACP), which called for the assimilation of blacks into American society as a way to eliminate racism. Also rejected was "petit bourgeois nationalist tendencies" in the black community originally attributed to Marcus Garvey who believed African Americans would achieve freedom by emigrating to a new nation outside of the United States. Instead, the CPUS line emphasized the role of a national revolutionary movement to eliminate capitalism that would create the environment for black workers to view themselves as a proletariat in unity with the white proletariat. The new movement would combine black self determination with radical changes in the structure of agrarian society in the Black Belt, a region of rich, dark soil stretching through part of Alabama and Mississippi, where large numbers of blacks worked on plantations since antebellum years. The changes would erase the continuing plantation system that persisted as part of American imperial and colonial policy following the Civil War. Although an ideological clash existed between communism on one hand and black nationalism, religion, and folklore on the other, historian Robin Kelley suggested that communists found common ground with these traditions. Despite rejecting racial politics as the basis for gaining social and political equality, communists attempted to reach out to blacks by interpreting their social and religious culture as "the genuine expression of the laboring and farming masses." 90

The CPUS responded vigorously to the call to work for racial equality, civil rights, and assistance with housing and relief for the poor, and it maintained this policy for the next 25 years. The Comintern's policy, however, disregarded American realities and the aspirations of the great majority of black workers. Despite efforts to recruit African Americans, relatively few joined and maintained membership for very long. ${ }^{91}$ Over the past 25 years some historians, such as Gerald Horne and Mark Naison, argued that party activities extended well beyond the Comintern's theoretical approach and the party's 
own revolutionary rhetoric. Horne and Naison emphasized how the CPUS promoted itself and integrated into black politics and social life in Harlem and influenced mainstream politics as a way to support the struggle for civil rights and equality. Yet Naison points out that party activities and rhetoric in support of Stalin's domestic and foreign policies during the 1930s and the war years led to discontent or rejection of the party within the African-American community. ${ }^{92}$

International Publishers produced a series of books on abolitionism, slave revolts, and emancipation as illustrated in works by James Allen, Herbert Aptheker, and Harry Haywood. In Negro Liberation (1932) Allen suggested that the oppressed state of black Americans in the industrial North and rural South was comparable to the subjugation and exploitation of workers and peasants under the yoke of colonial powers worldwide. Allen pointed to the Communist Party program as the way to achieve real democracy, equality, and eventually socialism for all people. ${ }^{93}$ In Negro Slave Revolts (1939) Aptheker rightly sought to correct the prevailing notion among many historians that American slavery was not harsh and that it was even beneficial to blacks, and he called on all Americans to join with blacks and "march forward ... against the common oppressors - against these industrial and financial overlords and the plantation oligarchs who today stand in the way of liberty, equality and prosperity" in order to defeat fascism, the slave system of the twentieth century ${ }^{94}$ After World War II Harry Haywood published his own Negro Liberation (1948) in which he also illustrated the party line on revolutionary change for African Americans. Haywood described in detail the continuing poor conditions for African Americans in the United States in the postwar years. He sought to demonstrate that the Community Party's program of eliminating racism through the unity of black workers, national consciousness, and selfgovernment in locations where blacks were the majority, would produce true democracy in American society. Haywood criticized moderate black "reformists" who attacked the party's labor program and compromised with American imperialism and colonialism at home and abroad. ${ }^{95}$ In these examples, the authors interpreted the nature of the African-American movement to eliminate racism and promote equal rights in American society in the context of revolutionary socialism and the promotion of the Communist Party. They used these issues to promote communist ideology as the solution for racism and civil rights rather than taking up these causes for their own sake.

Another important segment of International Publishers' program is the issue of peace and war. From the founding of his publishing firm in 1924, Trachtenberg produced publications extolling Soviet peacemaking and antiwar themes in general. After the Communist Party began the policy of the Popular Front against fascism, International Publishers continued with the same themes. The new emphasis, however, was opposition to fascism, a movement 
considered vital to the preservation of the Soviet Union. In 1936 the company published The Soviet Union and the Cause of Peace that mainly included writings and statements by Lenin, Stalin, Vyacheslav M. Molotov, and other Russian leaders. The editor explained that this book "confirms the fact that the strongest force for the preservation of peace today is the USSR with its sincere and unswerving peace policy and its Red Army."96 During the Spanish Civil War International Publishers put out works sympathetic to the Republican cause against Franco's fascism and communist renegades in books like In Salud! Poems, Stories and Sketches of Spain By American Writers (1938) and Trotskyism in the Service of Franco: A Documented Record of Treachery by the P.O.U.M. in Spain (1938). In the latter work, George Soria explained that the Trotskyist Workers Party of Marxist Unification not only perpetrated violence and sabotage against the government but also gave direct assistance to the fascists rebels. ${ }^{97}$

From the mid-1930s until the Nazi-Soviet Pact of 23 August 1939 communist literature reflected moderation in party rhetoric to seek common ground with democratic governments and the labor movements in America and Europe in the struggle against fascism. The agreement between Germany and the Soviet Union destroyed the Popular Front, already weakened by Congressional investigations into communist activities in the United States. Americans responded bitterly to the Soviet's reversal of policy, and the CPUS lost large numbers of members and sympathizers. The majority of party members stayed with the party and steadfastly defended the Soviet's action as good for peace in comparison with what they believed were the inept and militaristic policies of Britain, France, and the United States. Trachtenberg made public his support for the pact at the HUAC hearing less than a month after the agreement. $\mathrm{He}$ told the committee that all 100,000 party members individually decided that this as a good agreement because it saved Russia from war and helped Poland. ${ }^{98}$ In 1940 International Publishers published Earl Browder's Second Imperialist War, a collection of the Communist Party General Secretary's speeches, writings, and interviews from March 1939 until May 1940. Browder blamed the new war on capitalism and the imperialism of "so-called democratic governments" and he accused Britain and France of blaming the Soviet Union and not defending peace. He also spoke out against American participation in the war and defended the Soviet invasion of Finland as necessary for self-preservation, but he did not mention the Soviet invasion of Poland, which was part of a secret agreement attached to the Nazi-Soviet Pact. ${ }^{99}$

Browder's attitude toward the war and American rearmament contributed to his conviction for passport fraud and a four-year jail sentence. The party's antiwar approach and the publicity from the continuing HUAC hearings led Congress to pass the Alien Registration Act (Smith Act) in June 1940 that was used to arrest and convict persons based on comments and associations that 


\section{Lincove}

emphasized the use of force and violence to overthrow the US government. The party maintained its antiwar approach until the German invasion of the Soviet Union on 22 June 1941. Browder quickly switched his position and called for the defeat of Germany and preservation of the Soviet Union. He also supported the participation of the United States in the war. In Victory and After (1942) Browder emphasized Soviet-American unity in the war effort and called on communists to subordinate their desire for a socialist government so that victory in the war could be achieved. He also explained that communism was not the menace to America described by Hitler and the hated Dies Committee. ${ }^{100}$

Despite the new tone of unity with the mainstream, Americans continued to view communists with suspicion, and this mood intensified as the Soviet Union and the United States confronted each other in the Cold War that emerged at the end of World War II. During the Roosevelt Administration, but especially afterwards, accusations and Congressional investigations of communist influence in the federal government and involvement in Soviet espionage led directly to a new wave of arrests and trials of members of the CPUS beginning in 1949. Trachtenberg was part of the "second tier" of communist leaders who were swept up in the arrests and prosecutions of communists in 1951. Documents from his FBI file reveal that agents followed Trachtenberg's movements and associations on a daily basis, particularly since March 1941 when FBI Director J. Edgar Hoover "recommended that this individual be considered for custodial detention in the event of a national emergency" based on his record of leadership in the Communist Party, management of International Publishers, and associations with Soviet authorities. ${ }^{101}$ Many other documents compiled over several years in the 1940s show that informants and agents infiltrated the offices of International Publishers and gathered specific information from Trachtenberg's meetings and telephone conversations relating to publishing and his work for the Communist Party.

Trachtenberg's prosecution in federal court, based on the publication program of International Publishers, his teaching in communist led schools, such as the Jefferson School of the Social Sciences founded in New York in 1943, and his previous writings in support of a communist revolution in the United States, led to his conviction for violating the Smith Act. In his statement to the court at the time of his sentencing, he criticized the prosecution for treating him without regard to the total publication history of International Publishers but instead used "fragments selected at random" and disregarded the entirely open and lawful work carried out by his firm for 28 years. ${ }^{102}$ After spending three months in prison following his conviction on 2 February 1953, the decision was overturned when a government witness, Harvey Matusow, recanted his testimony. In 1956 a federal court convicted him a second time and sentenced him to one year in prison, but again, in 1958, the US Circuit Court of Appeals 
declared the conviction void. The court based its decision on a 1957 US Supreme Court ruling, Yates v. United States, that declared that the Smith Act did not apply to teaching or advocating the overthrow of the US government by force and violence as an abstract principle, but only to actions or advocating actions. ${ }^{103}$

At the time of his prosecution Trachtenberg had a wide range of organized supporters who believed that the Federal Justice Department violated his right to free speech and freedom of the press. To garner support for Trachtenberg, International Publishers distributed two pamphlets that argued his case, including Books on Trial: The Case of Alexander Trachtenberg, Director, International Publishers and Publisher on Trial: The Case of Alexander Trachtenberg, A Symposium, both published in 1952 with the assistance of the Committee to Defend Alexander Trachtenberg. Also, in the midst of his prosecution, International Publishers compiled Looking Forward (1954), an anthology marking the publisher's 30 th anniversary that included works in progress and scheduled for publication within the next two years. Trachtenberg illustrated the strength of his convictions by publishing new literature from seventeen American authors, including Howard Fast, Victor Perlo, William Z. Foster, and Sidney Finkelstein who challenged the American economic, social, and political establishment. In his introduction, Trachtenberg argued that the new book represented "the best traditions of labor, the democratic heritage, and the century-old Marxist tradition in the United States. This kind of literature cannot be legislated away; no court can imprison it out of the reach of thought.... Read and see what the bookburners would like to destroy in the flames of the anti-Communist hysteria."104 Ironically, Trachtenberg's defense of the freedom of expression and the freedom of the press would not be tolerated in a communist society that demanded strict adherence to party ideology. In fact, the Communist Party of the United States enthusiastically supported Smith Act prosecutions of hated sympathizers of Trotsky in 1941. ${ }^{105}$

Through the years of Trachtenberg's legal struggles, International Publishers continued to operate, but the government crackdown on communists contributed to the decline of sales and published books. The height of the publisher's output of new titles in the 1930s coincided with increasing interest in socialism and communism during the years of economic depression. The number of publications declined in the 1940s, and reached its lowest level in the $1950 \mathrm{~s}$ as public and private organizations eliminated suspected communists from their ranks and the pressure on the party and its members led to a drastic decline in membership. James Allen, who worked for the publisher and took over its leadership after Trachtenberg retired in 1962, told an interviewer that in the period of McCarthy and the Korean War "the market for our type of literature dried up almost completely. We just barely managed to hold on."106 Despite the setbacks International Publishers continued to produce a wide vari- 


\section{Lincove}

ety of Marxist and socialist oriented books on politics, society, literature, and the arts. During the early Cold War years Trachtenberg published U.S.S.R. and World Peace (1949), which provided a collection of speeches delivered in 1948 at meetings of the United Nations by Soviet Deputy Foreign Minister Andrey Vyshinsky, and Denis Pritt's The State Department and the Cold War (1948), a highly critical review of the agency's report, "Nazi-Soviet Relations, 19391941," based on its anti-Soviet tone. In addition to classical reprints and biographical works about Communist Party leaders published during the 1950s as previously mentioned, there were works on contemporary affairs and problems in the emerging third world, including José Marti and Cuban Liberation (1953) by Carols Rodriguez, Atomic Imperialism: The State, Monopoly, and the Bomb (1952) by James Allen, and The Negro in Southern Agriculture (1953) by Victor Perlo. Also in the 1950s were publications as diverse as Sidney Finkelstein's Realism in Art (1954), Harry Wells' Ivan P. Pavlov: Toward a Scientific Psychology and Psychiatry (1956), and Phillip Foner's Mark Twain: Social Critic (1958). The publisher experienced a significant increase in production and sales during the period of the civil rights and antiVietnam War movements in the 1960s. Allen described sales for 1969 as being ten times what they were in 1962 and higher in 1970 than at any time in the publisher's history. ${ }^{107}$ With the revived interest in left-wing causes, the time seemed right for a new examination of radical literature from the 1930s when former New Masses editor, Joseph North, edited New Masses: An Anthology of the Rebel Thirties (1969).

Trachtenberg's work within the party and International Publishers consumed his public life until his retirement in 1962, and his efforts brought him high regard among left-wing and some mainstream publishers and among party associates. ${ }^{108}$ As early as 1934 , on the occasion of the tenth anniversary of International Publishers and his 50th birthday, the editor of the French publishing house Editions Sociales Internationales described International Publishers as a "monument to proletarian science in the United States ... [by] promoting and distributing international Marxist literature and to acquaint the American people with the achievements of socialist instruction in the Soviet Union." 109 On the same occasion, party leader William Z. Foster emphasized his close working relationship with Trachtenberg over many years and the publisher's contributions to "upbuilding of the workers movement, to the building of our Party, to the laying of the foundations for the final struggle which will make our class the ruling class." 110 The Communist Party thought so highly of him that it honored him twice. The first event occurred in 1954 on his 70 th birthday when the National Committee cited his "lifetime of devoted and tireless leading activity in the labor and Marxist movement." 111 For his 80th birthday and 40th anniversary of International Publishers in 1964, the party held a big celebration at the Statler Hilton Hotel in New York in honor of his dedi- 
cated contributions to the movement. When the hotel management found out that the Communist Party had scheduled an event, they attempted to cancel the party's reservation, and it took an order from a state Supreme Court judge to force the hotel to fulfill the contract. ${ }^{112}$ Two years later, on 16 December Trachtenberg died of a stroke at the age of 82 , and was survived by his wife of 49 years, Rosalind Kohn Trachtenberg. They had no children.

After joining the Workers Party in December 1921 Alexander Trachtenberg developed into a disciplined communist openly dedicated to establishing a revolutionary socialist society in the Bolshevik tradition. Promoting communism through the party and International Publishers was his public life, and by the time of his retirement he was one of the very few party members still active since the founding of the Workers Party in 1921. He gave strong support to maintain the Communist Party over many years and strengthened its cause by publishing literature that presented the party's case for socialist revolution. Not only did he publish translations of classical works on revolutionary socialism and encourage writers who could produce works sympathetic with the cause, he published books on "progressive" issues that broadened and reinforced the party's message. Trachtenberg greatly added to the expanding body and variety of propaganda and radical literature in a period of increasing economic, political, and social stresses from the mid-1920s through the Cold War years. Although his dream of replacing capitalism and American democracy with revolutionary socialism failed, International Publishers offered alternative ideas and political paths that Americans could evaluate. During Trachtenberg's lifetime, millions of Americans may have sympathized with causes such as aid and justice for the poor, improving pay and safety for workers, and civil rights, but there was little sympathy for the Communist Party's strategy, perspective, and historical view for solving the problems and its close association with the Soviet Union. Despite the US government's aggressive surveillance and prosecution of Trachtenberg and other American communists, as well as its pursuance of suspected sympathizers, the persistent civil and economic freedoms inherent in American law provided International Publishers with the opportunity to contribute to the marketplace of ideas and counter the strong forces of political censorship in the name of national security.

\section{Notes}

${ }^{1}$ For text of the Smith Act (i.e. Alien Registration Act of 1940) see U.S. Statutes at Large, 54 Stat. 671. For stories and pictures see New York Times, 21 June 1951.

2 "Text of Indictment of 21 Communist Leaders on Conspiracy charges," New York Times, 21 June 1951, 16. 


\section{Lincove}

${ }^{3}$ Brief accounts of International Publishers may be found in Judith Bushnell, "International Publishers Company," in American Literary Publishing Houses, 19001980: Trade and Paperback, ed. Peter Dzwonkoski (Detroit: Gale Research, 1986), 196-198; and Jim Williams, "International Publishers," in Encyclopedia of the American Left, ed. Mari Jo Buhle et al., 2nd ed. (New York: Oxford University Press, 1998), 375-376.

${ }^{4}$ The day and year of birth are in dispute. Secondary sources indicate 1884 , and based on the timing of his 50th and 80th birthday celebrations in 1934 and 1964, 1884 is the year. On applications for a passport in 1922 and 1929, Trachtenberg wrote 23 November 1885. Information provided by Trachtenberg in the archive at Trinity College in New Haven, Conn., where he attended undergraduate school, also shows conflicting dates, with one showing 23 November 1885 and another 10 November 1884.

5 "Jewish War-Hero at Yale," The American Hebrew (8 March 1912), 559. See also A. L. Patkin, The Origins of the Russian-Jewish Labour Movement (Melbourne: F. W. Cheshire Pty., 1947), 267-269.

${ }^{6}$ Alexander Trachtenberg, "Editor's Foreword," in Lenin on the Jewish Question (New York: International Publishers, 1934), 3-4, 13.

7 Patkin, The Origins of the Russian-Jewish Labor Movement, 264-266; Melech Epstein, Pages From a Colorful Life: An Autobiographical Sketch (Miami: I. Block Publishing, 1971), 13-14. Galut means exile in Hebrew or any place outside of the original Jewish homeland.

${ }^{8}$ Epstein, Pages From a Colorful Life, 14.

9 Jonathan Frankel, Prophecy and Politics: Socialism, Nationalism, and the Russian Jews, 1862-1917 (Cambridge: Cambridge University Press, 1981), 139-140.

${ }^{10}$ Alexander Trachtenberg to Charles Ruthenberg, 16 January 1924. Microfilm reproduction of fond 515, opis 1 of Records of the Communist Party of the United States of America, (Moscow, Russia: Rossiiskii tsentr khraneniia i izucheniia dokumentov noveishei istorii, 1999-2000), reel 22, Delo 338, document 40. Trachtenberg wrote that he "joined the party" while in the Donetz Basin in 1904.

Il Editor's foreword to Alexander Trachtenberg, "The Role of the Students in the Russian Revolution," Yale Courant (November 1911), 22 found in Alexander Trachtenberg Papers, Box 1, folder 4, Wisconsin Historical Society. Information on Trachtenberg's experience in Russia also from an e-mail letter dated 18 December 2001 written by Peter Knapp, Archivist at Trinity College in Hartford, Conn. Knapp examined papers related to Trachtenberg's admission to Trinity that are available in the college archives.

${ }^{12}$ Frankel, Prophecy and Politics, 135.

${ }^{13}$ Ibid., 135, 454; See also Salo W. Baron, The Russian Jew Under Tsars and Soviets, 2nd ed. (New York: Macmillan, 1976), 73; Joseph Samuel, Jewish Immigration to the United States from 1880-1910 (New York: Columbia University, 1914), tables xii-xiii; Melech Epstein, The Jew and Communism: The Story of Early Communist Victories and 
Ultimate Defeats in the Jewish Community, U. S. A., 1919-1941 (New York: Trade Union Sponsorship Committee, 1959), 14-15.

14 Trachtenberg's height, hair color, and complexion are indicated on his US passport application in 1922 copied in Communist Use and Abuse of United States Passports, Hearing Before the Subcommittee to Investigate the Administration of the Internal Security Act and Other Internal Security Laws of the Committee on the Judiciary, United States Senate, Eighty-fifth Congress, Second Session (Washington: US Government Printing Office, 1958-59), 64-65.

15 Alexander Trachtenberg Papers, Box 2, folder 2, Wisconsin Historical Society. See also Bulletin of Yale University Alumni Directory of Yale University (New Haven, 1920), 364. For Trachtenberg's dissertation see The History of Legislation for the Protection of Coal Miners in Pennsylvania (New York: International Publishers, 1942). 16 "Sixth Annual Convention I.S.S.," Intercollegiate Socialist 3 (February/March 1915): 19. See also Max Horne, The Intercollegiate Socialist Society, 1905-1921: Origins of the Modern American Student Movement (Boulder: Westview Press, 1979), 67, 208; Harry W. Laidler, "Ten Years of I.S.S. Progress," The Intercollegiate Socialist 4 (December/January 1915/16): 17.

17 "Alexander Trachtenberg to the editor," Yale Daily News 38 (15 May 1915), 2 found in Alexander Trachtenberg Papers, Wisconsin Historical Society.

18 Alexander Trachtenberg, "Military Training and the Student," Intercollegiate Socialist 4 (April/May 1916): 14-16; "Lists Americans as Pacifists," New York Times, 25 January 1919, 1, 4. Prosecutions of socialists and communists were aided by the Espionage Act of 1917, 40 Stat. 219 and the Sedition Act of 1918, 40 Stat. 553. For Debs case see Debs v United States, 249 U.S. 211.

19 Algernon Lee, The Case of the Rand School (New York: Rand School of Social Science, 26 July 1919), 13.

${ }^{20}$ New York Call (14 February 1918): 4-5 found in Alexander Trachtenberg Papers, Box 3, Folder 7, Wisconsin Historical Society; Dorothy Swanson, "Rand School of Social Science," in Encyclopedia of the American Left, 2nd ed., 686.

${ }^{21}$ Written note from Alexander Trachtenberg Papers, box 2, folder 2.

22 Harry W. Laidler, "Notes From the Bellfort Conference," The Intercollegiate Socialist 6 (December/January 1917-18): 23.

23 The World (23 December 1917), 1 found in box 1, folder 6, Alexander Trachtenberg Papers, Wisconsin Historical Society.

24 For Trachtenberg's response to the March 1917 revolution see Alexander Trachtenberg, "The Russian Revolution," Intercollegiate Socialist 5 (April/May 1917): 28-29. For a retrospective response to the October Revolution see Alexander Trachtenberg, "Two Years of the Russian Revolution," Intercollegiate Socialist 7 (April/May 1919): 30-32. See also Joseph R. Conlin, “Introduction," Workers ' Council: Organ of Working Class Expression, no. 1-10, 1 April-15 December 1921 (New York: Greenwood Reprint Corp., 1968), 2. 
${ }^{25}$ Alexander Trachtenberg, address to the Socialist Local of New York on 19 November 1919 as transcribed in Revolutionary Radicalism: Its History, Purpose and Tactics...Being the Report of the Joint Legislative Committee Investigating Seditious Activities [Lusk Report], Filed April 24, 1920, in the Senate of the State of New York, part 1, vol. 1 (Albany: J. B. Lyon Co., 1920), 560.

${ }^{26}$ Theodore Draper, The Roots of American Communism (New York: Viking Press, 1957), 177-209, 330.

${ }^{27}$ Ibid., 330.

${ }^{28}$ Ibid., 99. Draper refers to Trachtenberg's speedy Americanization and the prestige he carried as a European and one who participated in the Revolution of 1905 . See also Trachtenberg's association with the International Ladies Garment Workers Union (ILGWU): "Trachtenberg With the International," Justice (4 June 1920): I; See also a letter with ILGWU masthead dated 5 October 1920 in the Alexander Trachtenberg Papers, Wisconsin Historical Society. For brief information on the Comintern see Paul Buhle, "Third International (Comintern)," in Encyclopedia of the American Left, 2nd ed., 819-820.

${ }^{29}$ Editorial, "The 'Centre' Again," Revolutionary Age 1 (12 April 1919): 3.

${ }^{30}$ Louis Fraina, "A Discussion of Party Problems," Revolutionary Age 1, 32 (24 May 1919): 7. See also Draper, The Roots of American Communism, 142-143.

${ }^{31}$ Draper, The Roots of American Communism, 143, 332; See also "Split in the Party," Revolutionary Age 1, 31 (17 May 1919): 6; "The Left Wing and the Socialist Party," Revolutionary Age 2, 4 (26 July 1919): 9.

32 Alex Bittelman, "From Left Socialism to Communism," The Communist 12 (September 1933): 853.

${ }^{33}$ Draper, The Roots of American Communism, 331.

${ }^{34}$ Alexander Trachtenberg, "The Socialist Party - A Victim of Inner Contradictions," The Workers' Council 1, 10 (15 December 1921): 156-157. See also Bertram D. Wolfe, A Life in Two Centuries (New York: Stein and Day, 1981), 162-163 for a colorful characterization of the Socialist Party that emphasizes its social and political diversity.

${ }^{35}$ Draper, The Roots of American Communism, 330-342.

${ }^{36}$ Irving Howe and Lewis Coser, The American Communist Party: A Critical History 1919-1957 (Boston: Beacon Press, 1957), 88-90, 105-108; Draper, The Roots of American Communism, 327-343.

${ }^{37}$ Alan M. Wald, Exiles from a Future Time: The Forging of the Mid-Twentieth-Century Left (Chapel Hill: University of North Carolina Press, 2002),78-79.

${ }^{38}$ Epstein, The Jew and Communism, 256.

39 Ted Morgan, A Covert Life: Jay Lovestone Communist, Anti-Communist, and Spymaster (New York: Random House, 1999), 77-104.

${ }^{40}$ Sidney Hook, Out of Step: A Unique Life in the 20th Century (New York: Harper \& Row, 1987), 97.

41 "Workers Name Ticket," New York Times, 31 July 1922, 15; “Two Men Running Against Connolly," New York Times, 7 October 1925, 3. 
${ }^{42}$ Letter from M. J. Johannes to the Department of Justice, 7 June 1924. Letter and additional documents on Trachtenberg's tour declassified December 2002 following author's Freedom of Information Act (FOIA) request from the FBI File for Alexander Leo Trachtenberg (file \#61-2115). Photocopies of the documents are in the author's possession.

${ }^{43}$ Alexander Trachtenberg to Nicholas Dozenberg, 17 June 1924. Microfilm reproduction of fond 515, opis 1 of Records of the Communist Party of the United States of America, (Moscow, Russia: Rossiiskii tsentr khraneniia i izucheniia dokumentov noveishei istorii, 1999-2000), reel 22, Delo 350, document 93.

44 Alexander Trachtenberg to Charles Ruthenberg, 24 October 1924. Microfilm reproduction of fond 515, opis 1 of Records of the Communist Party of the United States of America, (Moscow, Russia: Rossiiskii tsentr khraneniia i izucheniia dokumentov noveishei istorii, 1999-2000), reel 21, Delo 330, document 34-35.

45 A. Markoff, "Lenin on Agitation and Propaganda, and the Tasks of the Communist Party," The Communist 13 (January 1934), 107-112.

46 Daniel Mason, "A Prophecy that Became Truer With the Years," The Worker (27 December 1964): $5,9$.

47 Allen Ruff, "We Called Each Other Comrade": Charles H. Kerr \& Company, Radical Publishers (Urbana: University of Illinois Press, 1997), 86-89, 193-199, 204206.

48 Photocopies of original, signed documents illustrating the chronology of the founding of International Publishers were declassified January 2003 following the author's FOIA request from the FBI File for Alexander Leo Trachtenberg (file \#61-2115). Photocopies of the documents are in the author's possession. Among the documents are the "Certificate of Incorporation," (17 July 1924), "By-Laws," "Minutes of the First Meeting of the Board of Directors," (22 July 1924); "Transfer of Subscription," (22 July 1924); letters of resignation of the five directors, including Russell F. Thomas, M. S. Massberg, Sydney M. Kaye, A. Phillips, and Joseph F. Cassidy (22 July 1924); "Minutes of the Meeting of the Board of Directors of International Publishers Co. Inc," (26 December 1924).

49 "Dies Group Finds 'Millionaire Red'," New York Times, 14 September 1939, 25; Federal Bureau of Investigation, The Communist Party, USA: Funds and Finances 1919-1953 (Washington, DC: FBI, US Department of Justice, May, 1954), 24-25. Declassified 9 November 1988; Testimony of Alexander Trachtenberg on 13 September 1939 from Investigation of Un-American Propaganda Activities in the United States, Hearings before a Special Committee on Un-American Activities, House of Representatives, Seventy-six Congress, First Session on H. Res. 282. Vol. 7. September 5-9, 11-13, 1939 (Washington, 1939), 4866-4867, 4880-4884. Harvey Klehr, John Earl Haynes, and Kyrill M. Anderson, The Soviet World of American Communism (New Haven: Yale University Press, 1998), 139. For an additional reference to Heller see also "National Affairs," Time, 25 September 1939, 12-13. 


\section{Lincove}

${ }^{50}$ Trachtenberg's FBI file holds more than 5,000 pages of daily and monthly reports on his activities beginning in 1921 until his death in 1966. After a FOIA request by the author, selected pages equaling approximately 10 percent of the file are declassified.

${ }^{51}$ Kenneth O'Reilly, "Dies, Martin," in American National Biography, ed. John A. Garraty and Mark C. Carnes (New York: Oxford University Press, 1999), 588-589; See also Ellen Schrecker, Many Are the Crimes: McCarthyism in America (Boston: Little, Brown, 1998), 91-98.

52 Investigation of Un-American Propaganda Activities in the United States, 4867, 4913-4914, 4934.

${ }^{53} \mathrm{Ibid} ., 4909,4921$. Sales figures for 1925-1933 from a typed table organized by year and month labeled "Sales" in Alexander Trachtenberg Papers, box 2, folder 7, Wisconsin Historical Society.

${ }^{54}$ Ibid., 4868-4877, 4887, 4890-4891.

${ }^{55}$ Ibid., 4916-4917. Lists of bookstores appear on the back of various pamphlets published by International Publishers and Workers Library Publishers. See Earl Browder, Democracy or Fascism: Report of the Central Committee to the Ninth National Convention of the Communist Party of the U.S.A.(New York: Workers Library Publishers, 1936), back cover. Also see Herbert L. Packer, Ex-Communist Witnesses: Four Studies in Fact Finding (Stanford: Stanford University Press, 1962), 161 regarding Louis Francis Bundenz, former editor of the Daily Worker from October 1935 to October 1945 who comments on Trachtenberg's influence as quoted from a United States Senate hearing in 1951; "Exhibit 7," in Investigation of Communist Propaganda, Hearing Before a Special Committee to Investigate Communist Activities in the United States of the House of Representatives, Seventy-First Congress, 2nd Session. Pt. 1, vol. 2 June 18-19, 1930 (Washington, DC: Government Printing Office, 1930), includes a copy of a catalog of books for sale by Workers Library Publishers.

${ }^{56}$ Alexander Trachtenberg to Charles Ruthenberg, 24 October 1924.

${ }^{57}$ Attachment to John Edgar Hoover to L. M. C. Smith, Chief, Special Defense Unit, "Memorandum," 21 March 1941, page 6a of attachment. Documents declassified December 2002 following author's FOIA request from the FBI File for Alexander Leo Trachtenberg (file \#61-2115). Photocopies of the documents are in the author's possession.

${ }^{58}$ Investigation of Un-American Propaganda Activities in the United States, 4875-4877, 4891, 4893. Also regarding his relationship with Communist Party publishing see Alexander Trachtenberg, "Literature and the Elections," Daily Worker, 25 June 1932, 4, a newspaper clipping found in Alexander Trachtenberg Papers, box 1, folder 6, Wisconsin Historical Society. The article refers to propaganda distribution for the 1932 presidential election campaign of William Z. Foster and James Ford. Regarding Weiner's testimony see Investigation of Un-American Propaganda Activities in the United States, 4801-4803.

${ }^{59}$ Investigation of Un-American Propaganda Activities in the United States, 4935. 
60 "The Art of Selling Literature," Party Organizer 2, 7-8 (July-August 1928), 19-20; A. Markoff, "Reading and Study Circles: Instruments for Propaganda and Agitation," Party Organizer 2, 7-8 (July-August 1928): 20-21; "Organizing Study Groups," Party Organizer 3, 2 (March 1930): 8-9; "Reach the Million Masses with Marxist-Leninist Literature," Party Organizer 9, 7-8 (July-August 1936): 31-37; "Planning Literature Sales at Election Meetings," Party Organizer 9, 7-8 (July-August 1936): 37-39; Joe Fields, "Literature on Wheels," Party Organizer 10, 6 (June 1937): 27-30.

${ }^{61}$ Alexander Trachtenberg, "Literature to the Masses!" Party Organizer 11, 7 (July 1938): 30. See also Trachtenberg's "Raising the Circulation of "The Communist International' Journal of Communist Analysis and Opinion," Party Organizer 9, 11 (November 1936): 25-27.

62 Klehr, The Soviet World of American Communism, 141, 148; John Ear1 Haynes and Harvey Klehr, Venona: Decoding Soviet Espionage in America (New Haven: Yale University Press, 1999), 69.

${ }^{63}$ John W. Saltmarsh, Scott Nearing: An Intellectual Biography (Philadelphia: Temple University Press, 1991), 237.

64 Ibid., 240. See also Nearing's Making of a Radical: A Political Autobiography (New York: Harper \& Row, 1972), 149-154. On the subject of following party ideology see Wald, Exiles from a Future Time, 78; and Franklin Folsom, Days of Anger, Days of Hope: A Memoir of the League of American Writers, $1937-1942$ (Niwot, Col.: University Press of Colorado, 1994), 2. On the expectations of professional revolutionists see The Communist Party - A Manual of Organization (New York: Workers Library Press, 1935) in Investigation of Un-American Propaganda Activities in the United States, Special Committee on Un-American Activities, House of Representatives, $76^{\text {th }}$ Congress, $1^{\text {st }}$ Session on H. Res. 282, Appendix Pt. 1 (Washington, DC: Government Printing Office, 1940), 734.

65 Anna Rochester to Alexander Trachtenberg, 21 November 1934, in Alexander Trachtenberg Papers, Wisconsin Historical Society.

${ }^{66}$ Daniel Aaron, Writers on the Left: Episodes in American Literary Communism (New York: Columbia University Press, 1992), 221-223, 263.

${ }^{67}$ Wald, Exiles from a Future Time, 110-111, 112, (quote) 118.

68 Ibid., 263. See also a similar comment from Michael Gold as quoted from New Masses in Howe, The American Communist Party, 294.

${ }^{69}$ Ibid., 185. Wald quotes from a letter written by Joseph Freeman to Daniel Aaron, 3 July 1958, located in the Freeman Papers, Hoover Institute, Palo Alto, California.

${ }^{70}$ Investigation of Un-American Propaganda Activities in the United States, 4924-4925.

${ }^{71}$ Alexander Trachtenberg, "The Publishing of Marxist-Leninist Classics in the U.S.,"

Daily Worker (31 March 1938): 5, newspaper clipping in Alexander Trachtenberg Papers, box 1, folder 6, Wisconsin Historical Society. This article outlines the publishing program for 1938 with emphasis on publication of classic works.

${ }^{72}$ Yakov Yakovlev, Red Villages: The Five Year Plan in Soviet Agriculture (New York: International Publishers, 1931), 19, 123. See also Larry E. Holmes, "Yakovlev, Yakov 
Arkad'evich," in The Modern Encyclopedia of Russian and Soviet History, ed. Joseph L. Wieczynski et al., vol. 44 (Gulf Breeze, Fl.: Academic International Press, 1987), 168-172.

${ }^{73}$ George Anstrom, The American Farmer (New York: International Publishers, 1932), 4, 15-16, 21, 30-31.

${ }^{74}$ Investigation of Un-American Propaganda Activities in the United States, 4937-4939.

${ }^{75}$ Folsom, Days of Anger, Days of Hope, 91-92. See also B. A. Blois, "Socialist Realism," in The Modern Encyclopedia of Russian and Soviet History, vol. 44, 91-95.

${ }^{76}$ Alexander Trachtenberg, "Publishing Revolutionary Literature," in American Writers ' Congress (New York: International Publishers, 1935), 163. On the organization of the American Writers Congress see Aaron, Writers on the Left, 280-285.

77 Barbara Foley, Radical Representations: Politics and Form in U.S. Proletarian Fiction, 1929-1941 (Durham: Duke University Press, 1993): 84-85, 167-169, 146 (quote).

${ }^{78}$ Ibid., 148 (quote): 166-167. See also Aaron, Writers on the Left, 294-303. Aaron discusses the conflicts between New Masses and Partisan Review, and he suggests that literary infighting among communists was really just a minor concern to the Communist Party elite; Trachtenberg promoted quality literature in Partisan Review in Alexander Trachtenberg, "Revolutionary Literature," in Alexander Trachtenberg Papers, box 1, folder 6, Wisconsin Historical Society.

${ }^{79}$ Trachtenberg, American Writers' Congress, 162.

${ }^{80}$ Michael Denning, The Cultural Front: The Laboring of American Culture in the Twentieth Century (London: Verso, 1996), xx, 46-50, 56-64, 462.

${ }^{81}$ Aaron, Writers on the Left, 275-279.

82 Ibid., 274-275, 283-285.

${ }^{83}$ Ibid., 284. (Quote from Granville Hicks' conversation with Aaron).

${ }^{84}$ Joseph Freeman, "Introduction," in Proletarian Literature in the United States: An Anthology (New York: International Publishers, 1935), 9-28; Ralph Fox, The Novel and the People (New York: International Publishers, 1937), 14-15, 111-113.

${ }^{85}$ Michael Gold, The Hollow Men (New York: International Publishers, 1941), 123-128.

${ }^{86}$ Grace Hutchins, Labor and Silk (New York: International Publishers, 1929), 7-8, 161, 167.

${ }^{87}$ Max Beer, Social Struggles in the Middle Ages (New York: International Publishers, 1929), 11-12.

${ }^{88}$ Alexander Trachtenberg, The History of May Day (New York: International Publishers, 1931), 25-31. See also Alexander Trachtenberg, "May First-The Traditional Day of Proletarian Political Action," The Communist 9 (May 1930): 402-416.

89 James B. Allen, "Introduction," in Thomas Paine: Selections From His Writings (New York: International Publishers, 1937), 7, 21.

${ }^{90}$ Robin D. G. Kelley, Race Rebels: Culture, Politics, and the Black Working Class (New York: Free Press, 1994), 120-121. 
${ }^{91}$ Harry Haywood, Black Bolshevik: Autobiography of an Afro-American Communist (Chicago: Liberator Press, 1978), 142-143, 268-269, 420-421; Schrecker, Many Are the Crimes, 32-34; see also Howe, The American Communist Party, 206-216.

92 Gerald Horne, "The Red and the Black: The Communist Party and AfricanAmericans in Historical Perspective," in New Studies in the Politics and Culture of U.S. Communism, ed. Michael Brown et al. (New York: Monthly Review Press, 1993), 199237; Mark Naison, Communists in Harlem During the Depression (Urbana: University of Illinois Press, 1983), xv-xx, 248, 283. See also Mark Naison, "Remaking America: Communists and Liberals in the Popular Front," in New Studies in the Politics and Culture of U.S. Communism, 69-70.

${ }^{93}$ James S. Allen, Negro Liberation (New York: International Publishers, 1935), 16-23.

${ }^{94}$ Herbert Aptheker, Negro Slave Revolts in the United States, 1526-1860 (New York: International Publishers, 1939), 70.

${ }^{95}$ Harry Haywood, Negro Liberation (New York: International Publishers, 1948), 152$167,210-211$.

${ }^{96}$ [Unnamed Editor], "Foreword," in The Soviet Union and the Cause of Peace (New York: International Publishers, 1936), vi.

97 George Soria, Trotskyism in the Service of Franco: A Documented Record of Treachery by the P.O.U.M. in Spain (New York: International Publishers, 1938), 5-10.

${ }^{98}$ Investigation of Un-American Propaganda Activities in the United States, 4902-4903.

99 Earl Browder, The Second Imperialist War (New York: International Publishers, 1940), 103,150,154. See also press stories about party rallies in New York in support of the Nazi-Soviet Pact in New York Times, 7 September 1939, 18, and New York Times, 12 September 1939, 23.

${ }^{100}$ Earl Browder, Victory and After (New York: International Publishers, 1942), 14.

101 John Edgar Hoover to L. M. C. Smith, Chief, Special Defense Unit, "Memorandum," and attachments, 21 March 1941. Documents declassified December 2002 following author's FOIA request from the FBI File for Alexander Leo Trachtenberg (file \#61-2115). Photocopies of the documents are in the author's possession. The attachments outline the FBI's account of Trachtenberg's activities from his arrival in the United States in 1906 to February 1941. The agency received their information from secret informants, former party members, and publications.

${ }^{102}$ Alexander Trachtenberg, "Books are Living Things," New Masses 6, 4 (April 1953), 44-45.

${ }^{103}$ Alexander Trachtenberg Papers, box 3, folders 4, 9. For the court's ruling see United States of America, Plaintiff-Appellee, v. James E. Jackson, Sidney Stein, Fred Fine, Alexander Trachtenberg, William Norman, and George Blake Charney, DefendantsAppellants. No. 233, Docket 24445. "United States Court Of Appeals Second Circuit," 257 F.2d 830; 1958 U.S. App. 4576. 5 June 1958, Argued; 4 August 1958, Decided. Folder 9 includes copies of notices from Publisher's Weekly on his trial, including 22 May 1952, 30 April 1955, 27 August 1956, 18 August 1958, and an obituary on 16 December 1966. 


\section{Lincove}

${ }^{104}$ Looking Forward: Sections of Works in Progress By Authors of International Publishers on the Occasion of its Thirtieth Anniversary (New York: International Publishers, 1954), 8. On Trachtenberg's ideas regarding censorship see also Trachtenberg, "Books are Living Things," 46.

${ }^{105}$ Helen C. Camp, Iron in Her Soul: Elizabeth Gurley Flynn and the American Left (Pullman: Washington State University Press, 1995), 165.

106 Margrit Pittman, Daily Worker (13 June 1970), in box 2, folder 7, Alexander Trachtenberg Papers, Wisconsin Historical Society.

${ }^{107} \mathrm{Ibid}$. For an estimate of the trends in publishing, see also the library catalog at New York University which houses a large number of books from International Publishers.

${ }^{108}$ Wald, Exiles from a Future Time, 77-79. See also letters of appreciation from publishers and friends in Alexander Trachtenberg Papers, Wisconsin Historical Society in various folders; and "Trachtenberg, Marxist Leader, Dies at 82," The Worker (24 December 1966): 5 .

${ }^{109}$ Editions Sociales Internationales to Alexander Trachtenberg, 19 November 1934, Alexander Trachtenberg Papers, box 2, folder 6, Wisconsin Historical Society.

110 William Z. Foster to Alexander Trachtenberg, 1 December 1934, Alexander Trachtenberg Papers, box 6, Wisconsin Historical Society.

111 "Alexander Trachtenberg Dies: Top Publisher of Marxist Books," New York Times, 17 December 1966, 32.

${ }^{112}$ Ibid. See also "New York State Supreme Court Orders Hotel to Permit Meeting," New York Times, 15 January 1965, 18. 